Reprod. Nutr. Dévelop., 1984, 24 (4), 439-448.

\title{
A new method for studying pituitary responsiveness in vivo using pulses of LH-RH analogue in ewes passively immunized against native LH-RH
}

\author{
A. CARATY, G. B. MARTIN, G. MONTGOMERY $\left({ }^{\prime}\right)$
}

Station de Physiologie de la Reproduction, I.N.R.A., Nouzilly, 37380 Monnaie, France.

Summary. In two experiments with ovariectomized ewes, the plasma levels of LH and FSH were measured following passive immunization against LH-RH. The pulsatile secretion of $\mathrm{LH}$ was inhibited and the levels of the hormone fell quickly and were undetectable within $24 \mathrm{~h}$. The levels of FSH fell more slowly and were always detectable. In the second of the experiments, pulses of LH of normal amplitude were re-established in the immunized ewes by hourly intravenous injections of $200 \mathrm{ng}$ of Des-Gly10 (Pro9)-LH-RH Ethylamide, a synthetic analogue of $\mathrm{LH}-\mathrm{RH}$ that does not cross-react with the antiserum yet has similar biological activity to native LH-RH. The analogue was injected over $6 \mathrm{~h}$ and had no detectable effect on the levels of FSH. When the ewes were injected with $50 \mu \mathrm{g}$ of oestradiol benzoate, the $\mathrm{LH}$ responses to the analogue were completely inhibited for $4-5 \mathrm{~h}$ then slowly recovered to normal levels. The oestrogen injection also depressed the levels of FSH for varying amounts of time. On the basis of the normal LH patterns and responses to oestrogen, we conclude that combining passive immunization against LH-RH with injections of an $\mathrm{LH}-\mathrm{RH}$ analogue provides a valuable model for testing factors that affect pituitary responsiveness to $\mathrm{LH}-\mathrm{RH}$.

\section{Introduction.}

For both males and females, it has been proposed that the feedback system controlling the secretion of gonadotrophins operates at two levels, namely the hypothalamus and the anterior pituitary gland (for review: Martin, 1984). However, it has been difficult to determine experimentally the individual roles of these sites and their relative importance in the control of reproductive function. Studies on animals in which the hypophysial stalk has been sectioned have often been plagued by problems of pituitary infarction. Although this has been partly overcome in more recent work (Clarke, Cummins and De Kretser, 1983), these approaches have other major drawbacks. The lack specificity since they interfere with the secretion of other hormones secreted by both the anterior and posterior

(1) Present address : Invermay Agricultural Research Centre, Private Bag, Mosgiel, New Zealand. 
pituitary glands, the surgery is complex and time-consuming, and it is difficult to keep the operated animals in good health for long periods of time.

In contrast, immunological neutralization of the particular hypothalamic hormone being studied would overcome the questions of specificity and circumvent the need for difficult surgery and animal maintenance. The neutralized hypothalamic hormone could then be replaced with a synthetic analogue that does not cross-react with the antibodies in use, and pituitary responses to various treatments could thus be tested in vivo without interference from the hypothalamus.

It has been shown that active immunization against luteinizing hormonereleasing hormone ( $\mathrm{LH}-\mathrm{RH}$ ) will specifically and effectively inhibit the secretion of luteinizing hormone $(\mathrm{LH})$ and reduce the levels of follicle-stimulating hormone (FSH) in rams and ewes (Clarke, Fraser and McNeilly, 1978 ; Jeffcoate, Foster and Crighton, 1978 ; Lincoln and Fraser, 1979 ; Fraser and McNeilly, 1982). Furthermore, Fraser, Clarke and McNeilly (1981) have demonstrated that the secretion of the gonadotrophins can be stimulated in the immunized animals by injections of an LH-RH analogue, but they were unable to maintain normal patterns of secretion because they used a highly potent and long-acting compound that induced pituitary refractoriness.

We therefore decided to develop this model further by using an LH-RH analogue with a potency similar to naturally occurring $\mathrm{LH}-\mathrm{RH}$, and to test whether such a model could be used to study the effects of oestrogen on the secretion of $\mathrm{LH}$ and $\mathrm{FSH}$ by the anterior pituitary gland.

\section{Material and methods.}

Production of the antiserum. - The synthesis of the conjugate, LH-RHglutaraldehyde-human serum albumin, has been described previously (Caraty et al., 1980). The conjugate was dissolved in physiological saline, emulsified with Freund's complete adjuvant and used to immunize two ovariectomized Prealpesdu-Sud ewes. The antigen (1 $\mathrm{mg} \mathrm{LH}-\mathrm{RH}$ per $4 \mathrm{mg}$ human serum albumin) was injected intradermally (at about 40 sites) at weekly intervals for 4 weeks. One month later an intravenous booster injection (without adjuvant) was given and blood was collected 5 and 7 days later. After a further month, the immunization schedule was repeated and 6 days after the booster the animals were decapitated. The blood from the two ewes was collected, pooled, and allowed to coagulate at $4^{\circ} \mathrm{C}$. The serum was separated and stored at $-20^{\circ} \mathrm{C}$.

The titres and the cross-reactions exhibited by the antisera were measured in a radioimmunoassay system which has been described in detail elsewhere (Caraty et al., 1980). A highly specific antiserum was produced that bound $45 \%$ of the labelled $\mathrm{LH}-\mathrm{RH}$ at final dilutions of $1 / 50000$ and 1/150 000 after the first and second schedules of immunization, showing that repeated treatment with antigen can produce LH-RH antisera of high titre in the sheep. The binding of labelled hormone by the second batch of antiserum was reduced from $45 \%$ to $20 \%$ by the addition of $25 \mathrm{pg}$ of unlabelled hormone to the reaction mixture. Only the second batch of serum was used in the present experiments. 
Analogue to $L H-R H$. - To stimulate the secretion of gonadotrophins in animals that had been immunized against $\mathrm{LH}-\mathrm{RH}$, we injected intravenously a saline solution of the synthetic analogue Des-Gly10(Pro9)-LH-RH ethylamide (molecular formula : Glp-His-Trp-Ser-Tyr-Gly-Leu-Arg-Pro-NH-Ethylamide). The compound (cat. no. PB2206) was provided by Cambridge Research Biochemicals (Harston, Cambridgeshire, England) and has a biological activity between twofold (J. Sandow, 1978, pers. comm.) and five-fold (Fujino et al., 1972) that of native $\mathrm{LH}-\mathrm{RH}$. The cross-reaction of the analogue was very low lless than $0.001 \%$ at B/Bo $45 \%)$ and there was a complete absence of binding of analogue that had been labelled with iodine-125 (Caraty et al., 1980) in the presence of an excess (final titre 1/1 000) antiserum.

Experiment 1. - In September (early breeding season), blood was sampled every $10 \mathrm{~min}$ for $4 \mathrm{~h}$ from two Romanov ewes that had been ovariectomized six months previously. The following day (Day 0), the sampling procedure was repeated and the ewes were injected intravenously with $50 \mathrm{ml}$ of the $\mathrm{LH}-\mathrm{RH}$ antiserum. Blood samples were collected every $10 \mathrm{~min}$ for two hours on Day 10 and Day 30 to determine the duration of the effects of the antibody. Between Day 10 and Day 30, doses of 100, 200 and $400 \mathrm{ng}$ of the analogue were injected intravenously and on the basis of the responses we were able to select a dose $(200 \mathrm{ng})$ that evoked an LH pulse with an amplitude and duration similar to those of the endogenous pulses observed on the day prior to immunization. A large stock of the analogue was dissolved in physiological saline at a concentration of $100 \mathrm{ng} / \mathrm{ml}$ and frozen in aliquots for use in experiment 2.

In both experiments, indwelling jugular catheters were used to facilitate the injections and collection of blood samples. The samples were heparinized and centrifuged, and the plasma was separated and stored at $-20^{\circ} \mathrm{C}$ until assayed. To allow precise estimation of the amplitude of the responses to the injections of analogue, the first blood sample was always taken at a constant interval $(10 \mathrm{~min})$ after the injection.

Experiment 2. - In June (mid-anoestrus), blood was sampled every 10 min for $6 \mathrm{~h}$ from three Romanov $\times$ Prealpes ewes (ovariectomized for at least 6 months). The following day (Day 0 ), the sampling procedure was repeated and the ewes were immunized with $50 \mathrm{ml}$ of the antiserum. On Day 8, samples were collected for $6.5 \mathrm{~h}$ and after the first half-hour the ewes were injected hourly (total 6 injections, each of $200 \mathrm{ng}$ ) with the analogue to provide an artificial pulse regimen. The amplitudes (peak concentration-concentration at preceding nadir) of all of the endogenous pulses on Day-1 were measured for comparison with the amplitudes of the responses to the last five analogue injections on Day 8 . The response to the first injection was omitted from the analysis because it was not preceded by an inter-pulse nadir.

On Day 24, the artificial pulse regimen and sampling procedure were reimposed for $18 \mathrm{~h}$. Ten minutes after the second pulse of analogue, the ewes were injected intravenously with $50 \mu \mathrm{g}$ of oestradiol benzoate.

Radioimmunoassays. - The concentration of $\mathrm{LH}$ was measured with a double antibody radioimmunoassay (Pelletier et al., 1968). The limit of detection 
was $0.6 \mathrm{ng} / \mathrm{ml}$ and the intra-assay coefficient of variation was $10 \%$ at $\mathrm{B} / \mathrm{Bo}=70 \%(0.25 \mathrm{ng} / \mathrm{ml})$. The standard hormone preparation (CNRS LH-M3) has an activity of 1.8 units NIH-LH-S1 per mg. We measured the levels of FSH with a homologous radioimmunoassay (Blanc and Poirier, 1979) using the standard preparation CNRS-FSH-P26 with an activity of 36 units NIH-FSH-S3 per mg. The intra-assay coefficient of variation ranged from $4 \%$ (at $\mathrm{B} / \mathrm{Bo}=30 \%: 2 \mathrm{ng} /$ tube) to $7 \%$ (at B/Bo $=70 \%: 0.6 \mathrm{ng} /$ tube).

To avoid variation between assays, all samples for each hormone were measured in a single assay. Each hormone was measured in duplicate $50 \mu \mathrm{l}$ aliquots ( $\mathrm{LH}$ and $\mathrm{FSH}$ ) of plasma. Pulses of $\mathrm{LH}$ were defined as described by Goodman and Karsch (1980).

Statistical analysis. - Changes in the soncentrations of hormone within the same animal were tested for statistical significance by analysis of variance for repeated measurements (Sokal and Rohlf, 1969).

\section{Results.}

Experiment 1. - In both ewes the pulses of LH were inhibited by the injection of the antiserum (fig. 1). Remarkably, the levels of LH remained elevated and did not decline greatly during the $3.5 \mathrm{~h}$ of observation on Day 0. However, the hormone was undetectable on Days 2 and 10 in both ewes. In one ewe it had risen significantly $(P<0.001)$ by Day 30 . For FSH the decline was more progressive and much slower, becoming statistically significant by Day 2 for Ewe $1(P<0.001)$ and by Day $10(P<0.001)$ for Ewe 2 .

Experiment 2. - The immediate effects of passive immunization on the secretion of $\mathrm{LH}$ were similar to those seen in experiment 1 . The pulses

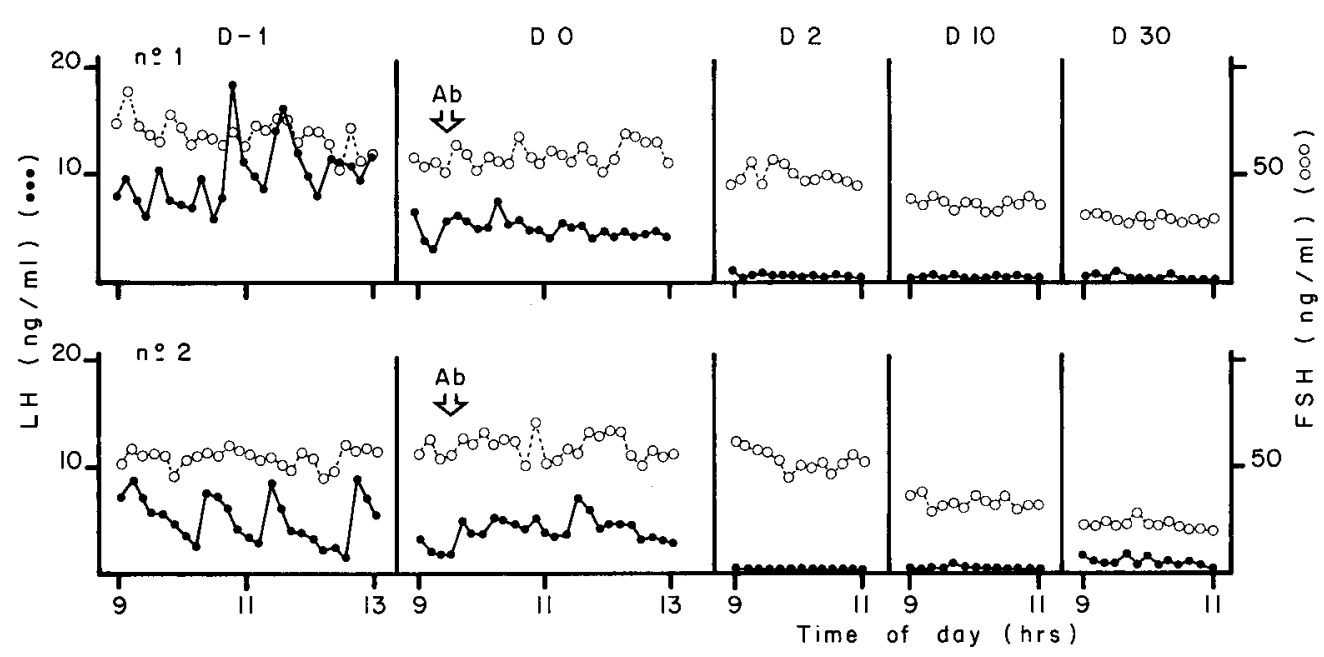

FIG. 1. - The secretion of $\mathrm{LH}$ and FSH

in two ovariectomized ewes following passive immunization against $\mathrm{LH}-\mathrm{RH}$. 
disappeared but the concentration of the hormone took some time to decline and in one ewe it even increased during the 2-h period immediately following treatment (Ewe 3, fig. 2). The observation period after immunization was longer in this experiment than in the first and a decline in concentration was visible during the first day. On Day 8 , serial injections of $200 \mathrm{ng}$ of the analogue regularly evoked episodes in the secretion of LH (fig. 2) with amplitudes very similar to the amplitudes of the endogenous pulses observed before treatment with the antiserum (table 1). Although there was little variation in the amplitude of the responses within a given profile, there was considerable variation between the ewes in their responses to the analogue.

On Day 24, three weeks after immunization, the concentrations of $\mathrm{LH}$ had increased significantly above those observed on Day 8 in all three animals.

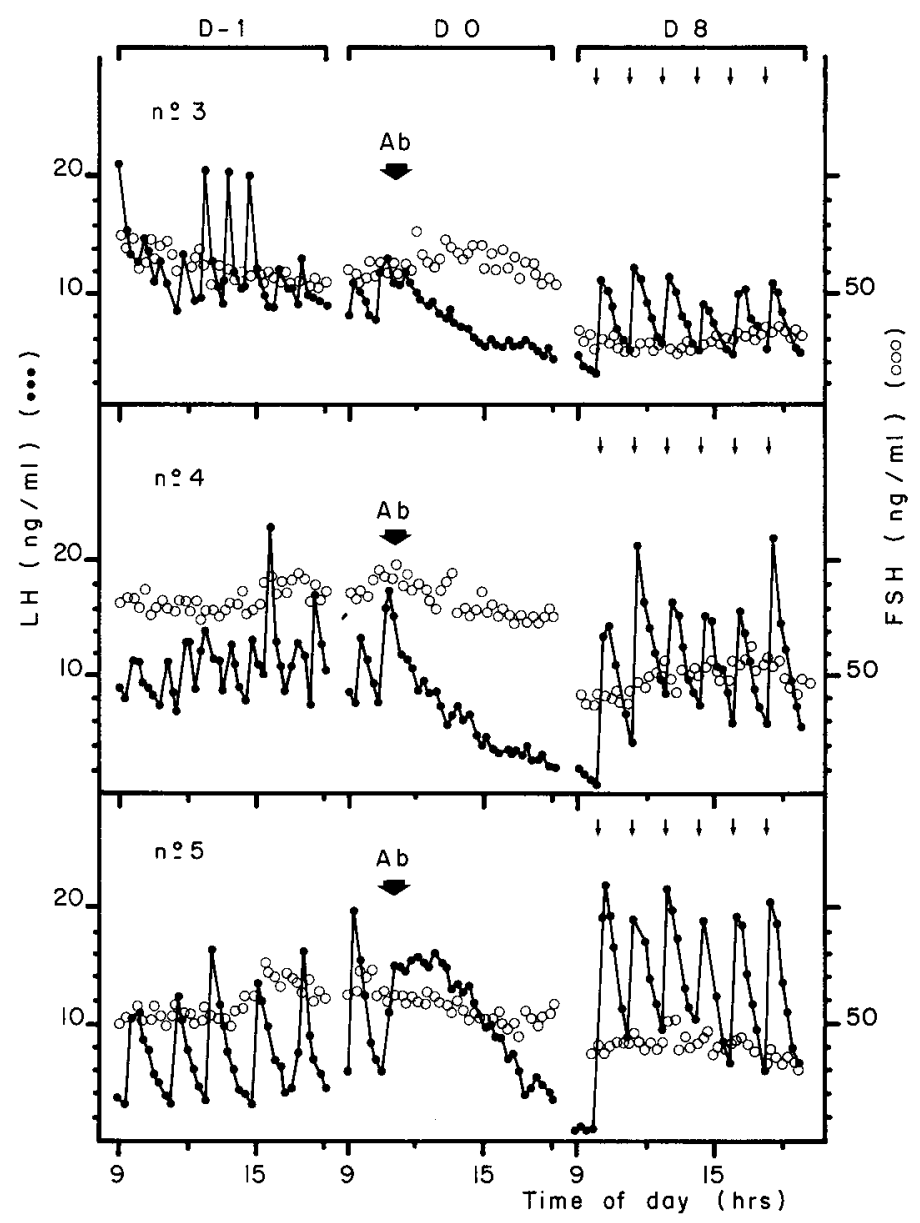

FIG. 2. - The secretion of $L H$ and FSH before $\left(D_{-1}\right)$ and following $\left(D_{0}\right)$ passive immunization against $\mathrm{LH}-\mathrm{RH}$ and replacement with a synthetic $\mathrm{LH}-\mathrm{RH}$ analogue $\left(\mathrm{D}_{8}\right)$. 
TABLE 1

Amplitudes of endogenous $L H$ pulses in three ovariectomized ewes before immunization against $\mathrm{LH}-\mathrm{RH}$ and after immunization and restoration of $\mathrm{LH}$ secretion with $200 \mathrm{ng} /$ injections of a synthetic analogue (experiment 2).

Pulse amplitude $(\mathrm{ng} / \mathrm{ml})$

\begin{tabular}{ccccccc} 
& \multicolumn{3}{c}{$\begin{array}{c}\text { Before immunization } \\
\text { Day-1 }\end{array}$} & & & \multicolumn{3}{c}{$\begin{array}{c}\text { After analogue } \\
\text { Day-8 }\end{array}$} \\
\hline Ewe & $n$ & mean + SEM & range & $n$ & mean + SEM & range \\
\cline { 4 - 6 } 3 & 8 & $6.2+1.5$ & $1.8-11.8$ & 5 & $5.7+0.5$ & $4.2-7.2$ \\
4 & 9 & $6.1+1.1$ & $3.6-13.0$ & 5 & $11.8+2.0$ & $7.7-17.2$ \\
5 & 5 & $10.7+1.0$ & $8.8-13.2$ & 5 & $12.1+0.9$ & $9.4-14.8$ \\
\hline
\end{tabular}

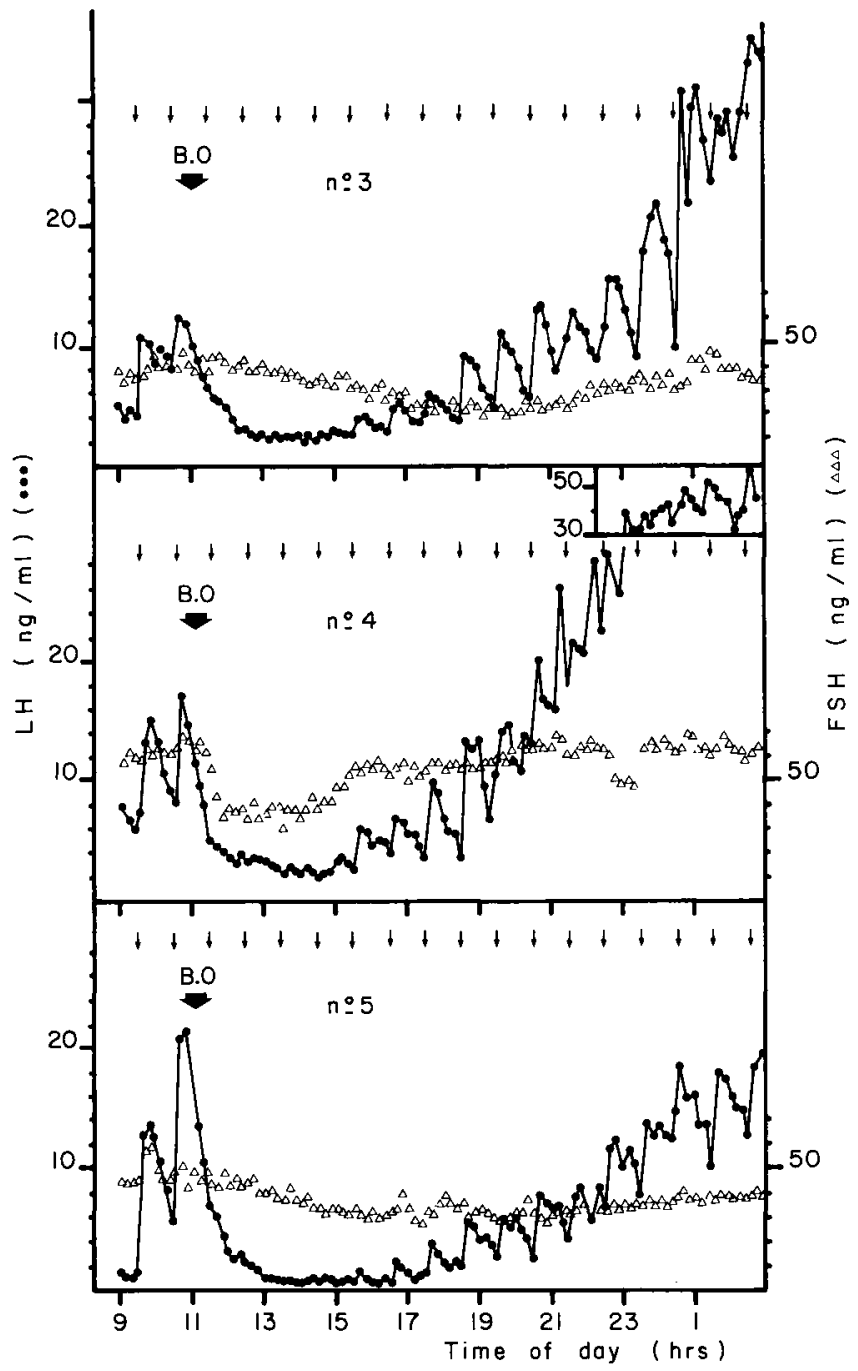

FIG. 3. $-D 24$ : the secretion of LH and FSH after oestradiol benzoate injection (50 $\mu \mathrm{g})$ in passively immunized ewes under an hourly analogue replacement regime. 
However, the amplitudes of the responses to the analogue were similar to those observed on Day 8. Immediately following the injection of oestrogen, all three ewes became completely insensitive to the analogue (fig. 3 ) and responses to the injections were undetectable for at least $4 \mathrm{~h}$.

The concentration of FSH was not obviously affected on the first day of immunization but was significantly reduced $(P<0.001)$ by Day 8 . There was no strong evidence for the release of pulses or for an increase in the level of FSH during the injections of analogue. The injection of oestrogen on Day 24 lowered the levels of FSH within 4-5 h in all three ewes (fig. 3), a rate of decline considerably greater than that observed after immunization against $\mathrm{LH}-\mathrm{RH}$ where several days were required for the effects to become detectable.

\section{Discussion.}

Passive immunization of ewes against $\mathrm{LH}-\mathrm{RH}$ rapidly blocked the secretion of $\mathrm{LH}$ pulses and within a one day of treatment the hormone could not be detected. The pulsatile pattern was then effectively re-established with hourly injections of small doses of the synthetic analogue, Des-Gly10 (Pro9)-LH-RH ethylamide. This contrasts with the findings of Fraser et al. (1981) who were unable to evoke regular responses in immunized ewes with-three-hourly injections of the analogue HOE766. The reason for this undoubtedly lies in the difference between the activities of the analogues: HOE766 is 50-100 times more active than native $\mathrm{LH}-\mathrm{RH}$ (Konig, Sandow and Geiger, 1975) whereas the product we used is only 2-5 times as active. The success of our regime of treatments indicates that the immunization/analogue model could be a useful tool for investigating the factors affecting the sensitivity and responsiveness of the anterior pituitary gland to $\mathrm{LH}-\mathrm{RH}$, and the role of these variables of pituitary function in the control of reproduction. This model has several advantages over the surgical techniques since it is specific for $\mathrm{LH}$ and $\mathrm{FSH}$, and it avoids complex surgery and animal maintenance. The principle behind the model might also be applied to studies of the secretion of other pituitary hormones.

Endogenously generated $\mathrm{LH}$ secretion began reappearing 20 days after immunization in both experiments indicating that insufficient antibody remained to bind all of the endogenous $\mathrm{LH}-\mathrm{RH}$. This agrees with the observation by Fraser and McNeilly (1983) that entire ewes recommence ovulatory cycles about 30 days after a single treatment with anti-LH-RH. Thus with passive immunization it would be necessary to give the animals and additional dose of the antiserum every three weeks. This increases the expense in terms of antiserum requirements, potentially the major factor limiting experimental designs. The use of active immunization would overcome this continued requirement, but control of the quantity and quality (especially with respect to affinity for the analogue) of the antibodies would be lost. Furthermore, considerable time is required to raise the antibodies so that actively immunized animals would be deprived of $\mathrm{LH}-\mathrm{RH}$ for long periods. This would probably affect pituitary function and therefore the results of tests of pituitary responses. 
The ability of the immunization/analogue model to reflect real physiological events is perhaps best demonstrated by the responses to the injection of a high dose of oestrogen. In all three ewes there was a rapid and complete loss of responsiveness to the pulses of analogue followed by a gradual recovery during which the LH pulse amplitudes increased progressively until they returned to normal size. The resulting LH profiles show effects that are strikingly similar to the responses to oestrogen injection described for ovariectomized monkeys (Yamaji et al. (1972) and ovariectomized ewes (Diekman and Malven, 1973 ; Davis and Borger, 1974).

Whereas the secretion of LH was rapidly blocked by immunization, the secretion of FSH changed quite slowly, taking several days to decrease significantly. Even after 24 days of deprivation of LH-RH, the concentrations did not reach those normally seen in entire ewes in this laboratory (Poindron et al., 1980), an observation that agrees with previous studies in ewes actively immunized against LH-RH (Clarke et al., 1978 ; Jeffcoate et al., 1978). This slow and incomplete effect was reflected in the lack of responsiveness to the pulses of analogue. These observations are consistent with those of Lincoln and Short (1980) who found that it was necessary to maintain treatment with exogenous pulses of native LH-RH for several days in order to increase the levels of FSH in rams. If the immunization/analogue model were to be useful for studying the secretion of FSH it would therefore seem essential to place the animals on a continuous regime of exogenous pulses.

In contrast with the slow fall in FSH levels following immunization, there was a rapid inhibition after the oestrogen injection as was observed by Fraser et al. (1981). When considered along with the lack of acute response to physiological doses of $\mathrm{LH}-\mathrm{RH}$ analogue, these observations are consistent with the hypothesis that control of tonic FSH secretion is not exerted at the hypothalamic level but through acute negative feedback exerted on the anterior pituitary gland by ovarian factors (including steroid hormones). There are also other lines of supporting evidence : ovariectomy of ewes that have been actively immunized against LH-RH leads to an increase in FSH levels (Clarke et al., 1978), and passive immunization against $\mathrm{LH}-\mathrm{RH}$ in entire ewes during the follicular phase leads to an increase in the levels of FSH, probably through deprivation of oestrogen (Fraser and McNeilly, 1983). Normally, FSH levels fall during the follicular phase due to the build-up in oestrogen levels (Baird and McNeilly, 1981).

In conclusion, in this report we have described an experimental model which should enable us to improve our understanding of pituitary function. Until now, studies of the effects of steroids on pituitary sensitivity and responsiveness to $\mathrm{LH}-\mathrm{RH}$ have always been difficult to interpret since the results could have been confounded by the effects of changes in the endogenous secretion of $\mathrm{LH}-\mathrm{RH}$. Furthermore, large and possibly non-physiological doses of LH-RH have often been necessary in order to evoke $\mathrm{LH}$ responses that can be measured above endogenous secretion. The immunization/analogue model should overcome these problems. 
Acknowledgements. - We would like to thank Dr J. Sandow of Hoescht A. G. (Frankfurt) for the great deal of help he gave us with the supply of analogues. G. B. Martin was supported financially by an Overseas Study Award granted by the Australian Meat Research Committee.

Résumé. Nouvelle méthode d'étude de la sensibilité hypophysaire à la $L H-R H$ in vivo, associant l'injection de pulses d'analogue à l'immunisation passive chez la brebis.

Lors de deux expériences consécutives les niveaux de LH et de FSH sont mesurés après immunisation passive contre la gonadolibérine ( $\mathrm{LH}-\mathrm{RH}$ ). Après injection de l'anticorps, la sécrétion pulsatile de LH est immédiatement inhibée et le niveau de cette hormone tombe rapidement devenant indétectable $24 \mathrm{~h}$ plus tard. Une décroissance partielle et beaucoup plus lente est observée pour les niveaux de FSH. Dans la deuxième expérience, la sécrétion pulsatile de LH est restaurée grâce à des injections successives d'un analogue le Des-gly10 (Pro-9)-LH-RH éthylamide qui n'est pas neutralisé par l'antisérum et dont l'activité biologique est voisine de celle du décapeptide naturel.

Quand les brebis reçoivent une injection intra-veineuse de $50 \mu \mathrm{g}$ de benzoate d'œstradiol, la réponse $\mathrm{LH}$ aux pulses d'analogue est complètement supprimée durant 4 à $5 \mathrm{~h}$ puis redevient progressivement normale. L'injection d'œstrogène entraîne également une diminution des niveaux de FSH.

Sur la base des profils de sécrétion de $\mathrm{LH}$, de la réponse aux œstrogènes, nous pouvons conclure que l'immunisation passive associée à des injections d'analogue de la gonadolibérine représente un modèle intéressant pour étudier les facteurs qui peuvent moduler la réponse hypophysaire à la LH-RH.

\section{References}

BAIRD D. T., McNEILLY A. S., 1981. Gonadotrophic control of follicular development and function during the oestrous cycle of the ewe. J. Reprod. Fert., suppl. 30, 119-133.

BLANC M. R., POIRIER J. C., 1979. A new homologous radioimmunoassay for ovine folliclestimulating hormone : development and characterization. Ann. Biol. anim. Bioch. Biophys., 19, 1011-1026.

CARATY A., de REVIERS M.-M., PELleTIER J., DUBOIS M. P., 1980. Reassessment of LRF radioimmunoassay in the plasma and hypothalamic extracts of rats and rams. Reprod. Nutr. Dévelop., 20, 1489-1501.

CLARKE I. J., CUMMINGS J. T., de KRETSER D. M., 1983. Pituitary gland function after disconnection from direct hypothalamic influences in the sheep. Neuroendocrinology, 36, 376-384.

CLARKE I. J., FRASER H. M., MCNEILLY A. S., 1978. Active immunization of ewes against luteinizing-hormone releasing-hormone and its effects on ovulation and gonadotrophin, prolactin and ovarian steroid secretion. J. Endocr., 78, 39-47.

DAVIS S. L., BORGER M. L., 1974. Dynamic changes in plasma prolactin, luteinizing-hormone and growth hormone in ovariectomized ewes. J. anim. Sci, 38, 795-802.

DIEKMAN M. A., MALVEN P. V., 1973. Effect of ovariectomy and estradiol on LH patterns in ewes. J. anim. Sci, 37, 562-567.

FRASER H. M., CLARKE I. J., McNEILLY A. S., 1981. Effect of oestrogen and an LH-RH agonist on the release of gonadotrophins in ovariectomized ewes deprived of LH-RH. J. Reprod. Fert., 62, 131-140.

FRASER H. M., McNEILLY A. S., 1982. Effect of immunoneutralization of luteinizing-hormone releasing-hormone on the estrogen-induced luteinizing-hormone and follicle-stimulating hormone surges in the ewe. Biol. Reprod., 27, 548-555.

FRASER H. M., McNEILLY A. S., 1983. Differential effects of LH-RH immunoneutralization on LH and FSH secretion in the ewe. J. Reprod. Fert., 69, 569-577. 
FUJINO M., KOBAYASHI S., OBAYASHI M., SHINAGAWA S., FUKUDA T., KITADA C., NAKAYAMA R., YAMAZAKI I., 1972. Structure-activity relationships in the C-termınal part of luteinizing-hormone releasing-hormone (LH-RH). Bioch. biophys. Res. Comm., 49, 863869.

GOODMAN R. L., KARSCH F. J., 1980. Pulsatile secretion of luteinizing-hormone in the ewe: differential suppression by ovarian steroids. Endocrinology, 107, 1286-1290.

JEFFCOATE I. A., FOSTER J. P., CRIGHTON D. B., 1978. Effect of active immunization of ewes against synthetic luteinizing-hormone releasing-hormone. Theriogenology, 10, 323-335.

KONIG W., SANDOW J., GEIGER R., 1975. In RAND W., MEIENHOFER J., Peptıdes : chemistry, structure and biology, p. 883. Ann. Arbor Sci. Publ., Ann. Arbor, Michigan.

LINCOLN G. A., FRASER H. M., 1979. Blockade of episodic secretion of luteinizing-hormone in the ram by the administration of antibodies to luteinizing-hormone releasing-hormone. Biol. Reprod., 21, 1239-1245.

LINCOLN G. A., SHORT R. V., 1980. Seasonal Breeding: nature's contraceptive. Rec. Progr. Horm. Res., 36, 1-52.

MARTIN G. B., 1984. Factors affecting the secretion of luteinizing-hormone in the ewe. Biol. Rev. (in press).

PELLETIER J., KANN G., DOLAIS J., ROSSELIN G., 1968. Dosage radioimmunologique de I'hormone lutéinisante plasmatique chez le mouton. Mise au point de la technique de dosage. C. R. Acad. Sci., Paris, Sér. D, 266, 2291-2294.

POINDRON P., COGNIE Y., GAYERIE F., ORGEUR P., OLDAM C. M., RAVAULT J. P., 1980. Changes in gonadotrophins and prolactin levels in isolated (seasonaly or lactationally) anovular ewes associated with ovulation caused by the introduction of rams. Physiol. Behav., 25. 227-236.

SOKAL R. A., ROHLF F. J., 1969. Biometry (Freeman, San Fransisco).

YAMAJI T., DIERSCHKE D. J., BHATTACHARYA A. N., KNOBIL E., 1972. The negative feedback control by estradiol and progesterone of $\mathrm{LH}$ secretion in ovariectomized Rhesus monkeys. Endocrinology, 90, 771-777. 